\title{
Supraorbital Keyhole Approach for Anterior Circulation Aneurysms
}

\author{
Anterior Dolaşım Anevrizmaları İcin Supraorbital Anabtar Deliği \\ Yaklaşımı
}

Chao TANG ${ }^{1}$, Jun $\mathrm{SUN}^{2}$, Hongli $\mathrm{XUE}^{3}$, Yong $\mathrm{YU}^{3}$, Feng $\mathrm{XU}^{3}$

${ }^{1}$ Huashan Hospital Affiliated to Fudan University, Department of Neurosurgery, Shanghai, China

${ }^{2}$ Xinhua Hospital of Hubei Province, Department of Neurosurgery, Wuban Hubei, China

${ }^{3}$ The General Hospital of Shenyang Military Region, Department of Neurosurgery, Shenyang Liaoning, China

Corresponding Author: Chao TANG / E-mail: tangchao314159@aliyun.com

\section{ABSTRACT}

AIM: Supraorbital keyhole approach provides access to the major part of the anterior circulation aneurysms. Herein, our surgical experience of supraorbital keyhole approach and its some modification have been proposed.

MATERIAL and METHODS: Out of a series of 76 patients harboring 80 aneurysms operated on via a supraorbital keyhole approach with a superciliar or front wrinkle skin incision, there are 70 patients with subarachnoidal bleeding, others are nonruptured aneurysms, Intraoperative rupture occurred in 8 cases, and 4 had multiple aneurysms.

RESULTS: There was a good cosmetic results with less approach-related complications .Of 80 aneurysms, 75 aneurysms were clipped successfully by the supraorbital route. Good Glasgow Outcome Scale scores of 4 or 5 were achieved in $95 \%$ of the patients at the time of discharge. 2 patients of Grade IV died in the postoperative period due vasospasm.

CONCLUSION: The supraorbital route is recommended for selected anterior circulation aneurysms based on the improved surgical instruments and microsurgical skills.

KEYWORDS: Supraorbital craniotomy, Keyhole approach, Anterior cerebral aneurysms

\section{Öz}

AMAÇ: Supraorbital anahtar deliği yaklaşımı anterior dolaşım anevrizmalarının büyük bir kısmına erişim sağlar. Burada supraorbital anahtar deliği yaklaşımı ve bazı modifikasyonları ile cerrahi deneyimimiz verilmektedir.

YÖNTEM ve GEREÇLER: Bir süpersiliyer veya ön kırışıklık cilt insizyonu yoluyla supraorbital anahtar deliği yaklaşımıyla ameliyat edilen, 80 anevrizmanın bulunduğu 76 hastadan oluşan seride 70 hastada subaraknoid kanama görülürken diğerlerinde anevrizma rüptürü yoktu. İntraoperatif rüptür 8 olguda oluştu ve 4 olguda birden fazla anevrizma vardı.

BULGULAR: Yaklaşımla ilgili olarak daha az komplikasyonla daha iyi kozmetik sonuçlar elde edildi. 80 anevrizma içinde 75 anevrizma supraorbital yolla başarıyla klipslendi. Taburcu etme zamanında hastaların yüzde 95 'inde 4 veya 5 şeklinde İyi Glasgow Sonuç Ölçeği puanları mevcuttu. 2 Evre IV hasta postoperatif dönemde vazospazm nedeniyle öldü.

SONUÇ: Supraorbital yol, gelişmiş cerrahi aletler ve mikrocerrahi becerileri temelinde seçili anterior dolaşım anevrizmaları için önerilir.

ANAHTAR SÖZCÜKLER: Supraorbital kraniyotomi, Anahtar deliği yaklaşımı, Anterior serebral anevrizmalar

\section{INTRODUCTION}

Many different conventional approaches, such as frontal and pterional approach are used to access anterior circulation aneurysms. These approaches provide excellent exposure to anterior and middle crania fossa. The major limitation of these approaches is a extended openings to expose the orbital rim. In recent decades, development of surgical instruments and microsurgical skills allows neurosurgeons to use smaller and more specific approaches to treat these lesions in the same region. One of these approaches, supraorbital subfrontal craniotomy offer a minimally invasive approaches to variety of lesions which has been reported (5). Recently, this approach has been widely applied to the treatment of anterior circulation aneurysms $(4,7)$. Here, we typically use this skin incision and craniotomy with moderate midification in the treatment of a variety of anterior circulation aneurysms.

\section{PATIENTS and METHODS}

\section{Clinical Material}

Between February 2008 and November 2011, all consecutive 76 patients with 80 anterior circulation aneurysms were treated. Data on Patient's medical records aneurysms characteristics (Table I), intraoperative and postoperative complications and surgical outcomes of patients were collectd and reviewed. 


\section{Supraorbital Craniotomy}

The patients are placed in supine position and angled 20 to 30 degrees to the contralateral side based on the location of the lesion. The patient's head is slightly retroflected with the malar eminence most superiorly. The skin incision is made within front wrinkle or in the eyebrow; the incision remains superficial to avoid injury to the supraorbital nerve. The skin flap is retracted superiorly with strong silk sutures to gain supraorbital exposure. To avoid injury to the frontalis branch

Table I: Characteristics of Aneurysms

\begin{tabular}{|l|r|}
\hline Aneurysm locations & No of cases \\
\hline Anterior cerebral artery & 4 \\
\hline Proximal to anterior communicating & 33 \\
\hline Anterior communicating & 37 \\
\hline Subtotal & \\
\hline Internal carotid artery & 3 \\
\hline Prociaml or ophthalmic region & 13 \\
\hline Posterior communicating region & 2 \\
\hline Other internal carotid & 18 \\
\hline Subtoal & 5 \\
\hline Middle cerebral artery & 12 \\
\hline Proximal to bifurcation & 17 \\
\hline Bifurcation & 4 \\
\hline Subtotal & 76 \\
\hline Multiple cerebral aneurysms*
\end{tabular}

* In these cases, 2 patients has multiple aneurysms on the both side in the middle cerebral artery. or on the both internal carotid artery -pcoa cerebral artery. 1 case had an anterior communicating artery aneurysm accompanied by an ophthalmic artery aneurysm(ipsilaleral) and in 1 cases, posterior communicating artery aneurysms were accompabnied by a contralateral medial posterior communicating artery aneurysm. of the facial nerve, fascial opening is limited. The frontal muscle is incised parallelly to the glabella and the frontal and orbicular muscles is stripped from its bony insertion and gently pushed. A single burr hole is placed below the superior temporal line and posterior to the keyhole. A small supraorbital craniotomy of approximately 15 to $20 \mathrm{~mm}$ by 20 to $25 \mathrm{~mm}$ is formed. The inferior aspect of the frontal bone at the orbital rim is drilled down so as to make orbital rim as low as possible. Bony protuberances along the floor of the frontal fossa should be drilled as well to provide better exposure to the floor of the anterior fossa. If the frontal sinus was entered, it can be repaired with abdominal fat and the pericranial flap. (Figure 1A-C).

The dura was opened with a curved incision with its base toward the orbital rim. From this stage of operation, the microscope was used, then the standard microsurgical procedure was carried out. Under microscopic visualization, the olfactory tract is identified and followed back to the ipsilateral optic nerve and carotid cistern. The arachnoid of the Sylvian fissure, the olfactory and suprasellar is opened sharply for drainage of CSF and further brain relaxation. A self-retaining brain retractor can be placed over the frontal lobe. Conventional microsurgical aneurysms surgery was performed. At the end of operation, the dura is closed in a watertight manner. The bone flap is fixed with the gaps between the bone flap and calvarium filled with collagen sponge.

\section{RESULTS}

\section{Surgical Findings}

All patients with nonruptured aneurysms were clipped on the day of admission. For those 70 cases with ruptured aneurysms. 58 were performed on day 1-3. In another patient, the clipping was performed 12 days after rupture. The size of the aneurysm was between 5 and $19 \mathrm{~mm}$.

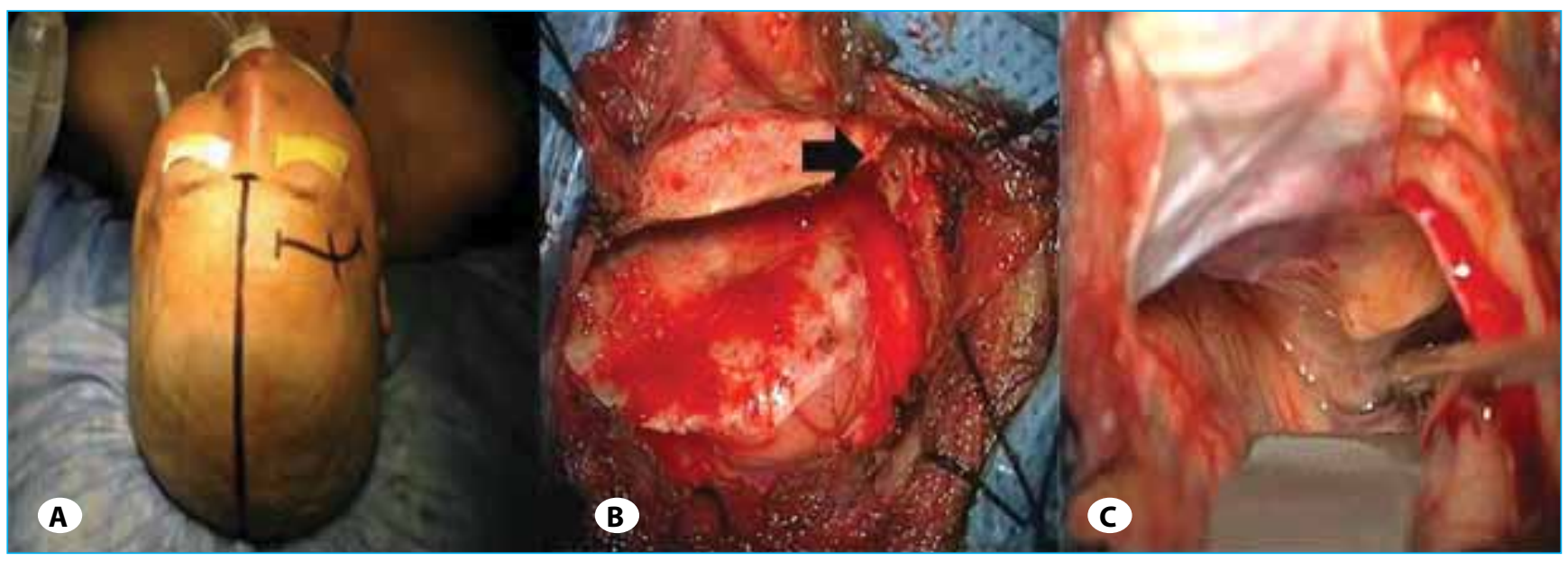

Figure 1: Intraoperative photographs of procedure in supraorbital craniotomy. (A) skin incision is planned within front wrinkle. (B) the muscular and skin flaps have been retracted with silk sutures, a single burr hole (arrow) is made below the superior temporal line and posterior to the keyhole, then a small supraorbital craniotomy is formed. (C) the dura is opened with base along the orbital rim. 
A temporary clip was used in 70 patients with an average time of 3.1 min (ranging between 0 and 10.35 minutes). After wide lysis and release of CSF, parent vessel (internal carotid, A1 and M1) could be exposed for temporary clip in all patients, There were intraoperative rupture in 8 cases, 2 rupture occurred at the time of neck dissection (Pcom) and 6 at time of clip application (Acom 4, Mca 2). For these cases, safe clipping was finally achieved with the use of the suction device and good visualization of the anatomy was maintained. Ful visualization of final location of the clip blades and tips and the perforator branches and their course can be achieved at the end of clip application in every case.

\section{Clinical Outcome and Complications}

Postoperative angiography was performed on all patients, demonstrating that successful and complete clipping was achieved in 75 (94\%), and the incomplete occlusion (partial clipping, wrapping, and no attempt) rate was $6 \%$. Two Grade IV patients died in the postoperative period due to vasospasm. 68 (95\%) patients achieved good Glasgow Outcome Scale scores of 4 or 5.4 patients developed a transient short-term functional neurological deficit, with full recovery within 3 to 6 months. 3 patients developed a cerebrospinal fluid leak, 2 underwent spontaneous cure, and the other was later repaired with transsphenoidal endonasal surgery. Secondary seizures occurred in 4 patient controlled by anti-seizure medication.

There were few approach-related complications. Five patients experienced permanent partial supraorbital hypesthesia as a result of lesion of the supraorbital nerve, but there was no depression of the operated site and palsy of the frontal muscle. Permanent unilateral hyposmia occurred in 6 patients. There was no frontalis branch palsy of the facial nerve. Wound healing disturbances were not observed.

\section{DISCUSSION}

We take the supraorbital craniotomy as the frontal part of classic pterional approach and a modification of previously reported approaches in the treatment of anterior circulation aneurysms (1,3). For some cases, it makes no sense to expose extensive areas of the brain, which may result in greater brain exposure to air, incidence of infection, trauma by brain retraction, herniation, and epilepsy. More importantly, the utility of the supraorbital route lies in a truth that majority of anterior circulation aneurysms are free to a surgical dissection from an anterior direction of view and the anterior part of the part temporal lobe does not obscure access to the deepseated areas.

Supraorbital craniotomy has been shown to be effective and safe for anterior circulation aneurysms. This approach has the advantages of less operative time, less retraction for brain tissue with a similar rate of complications related to the surgical treatment of anterior circulation aneurysms when compared with conventional approaches (6). Along with this rationale, we present our experience in clipping 80 anterior circulation aneurysms here.
The good aesthetic outcome is typically mentioned resulting from the short skin incision within the eyebrow in the supraorbital approach (2), However, it is sometimes difficult to achieve a best possible cosmetic results because some patients have short eyebrow and incision must be extended off the eyebrow onto the lateral side of the head. Moreover, eyebrows possibly increase the risk of postoperative wound infection. In some cases of our series, the skin incision was made within the front wrinkle or concealed behind the hairline. Our experience has shown that this incision also can achieve an optimal cosmetic outcome similar to the incision hidden by the eyebrow (Figure 2A-D).

This approach provides access to the majority of the anterior circulation aneurysms, except those located at the distal anterior cerebral artery. With this approach, we successfully clipped aneurysms located in the ipsilateral internal cartoid artery, anterior communicating artery, middle cerebral artery and posterior communicating artery in the past years, and this approach has been tested in the effective management of anterior communicating artery aneurysms by other authors (4).

MCA bifuration aneurysms in our series are located in the bifurcation of main trunk (M1) or between the bifurcation of the internal carotid artery (ICA) and the main bifurcation of MCA. In some case, the M1 segment is long, some authors take it as a contraindication to use the supraopbital keyhole approach. However, accroding to our experience, it is adequant to achieve access to the aneurysm, regardless the variations of the trajectory of the M1 segment, the M1 segment always runs within the carotid cistern, the aneurysms will be identificated when the sylvian fissure was entered in its middle portion. In some cases, there is no need to expose the entire M1 segment to find the aneurysm or even to find a portion of the M1 segment for proximal control. For distal MCA aneurysm that originate from branches of MCA distal to the main bifurcation or the peripheral branches, we recommend the pterional approach.

Acom aneurysms account for as many as $48 \%$ of series and are among the most difficult lesions to manage surgically. Anterior communicating complex aneurysms are excluded from subfrontal approach by some surgeon considering the difficulty in controlling the contralateral proximal vessels (8). However, for most cases, even the contralateral vessels have not been exposed, it is often possible to clip the aneurysm. It is difficult to exposure if the dome of aneurysms point superiorly and highly within the interhemispheric fissure, resection of the gyrus will be helpful.

For posterior communicating complex aneurysms the angle of vision with the subfrontal approach is not good, when the dome of aneurysms has a caudal direction. In these patients, clipping may be incomplete if a remmant dome is left unless the aid of a surgical neuroendoscope, if this device is not available, we prefer to use pterional approach in which visualization of the neck area of aneurysm will be better. 

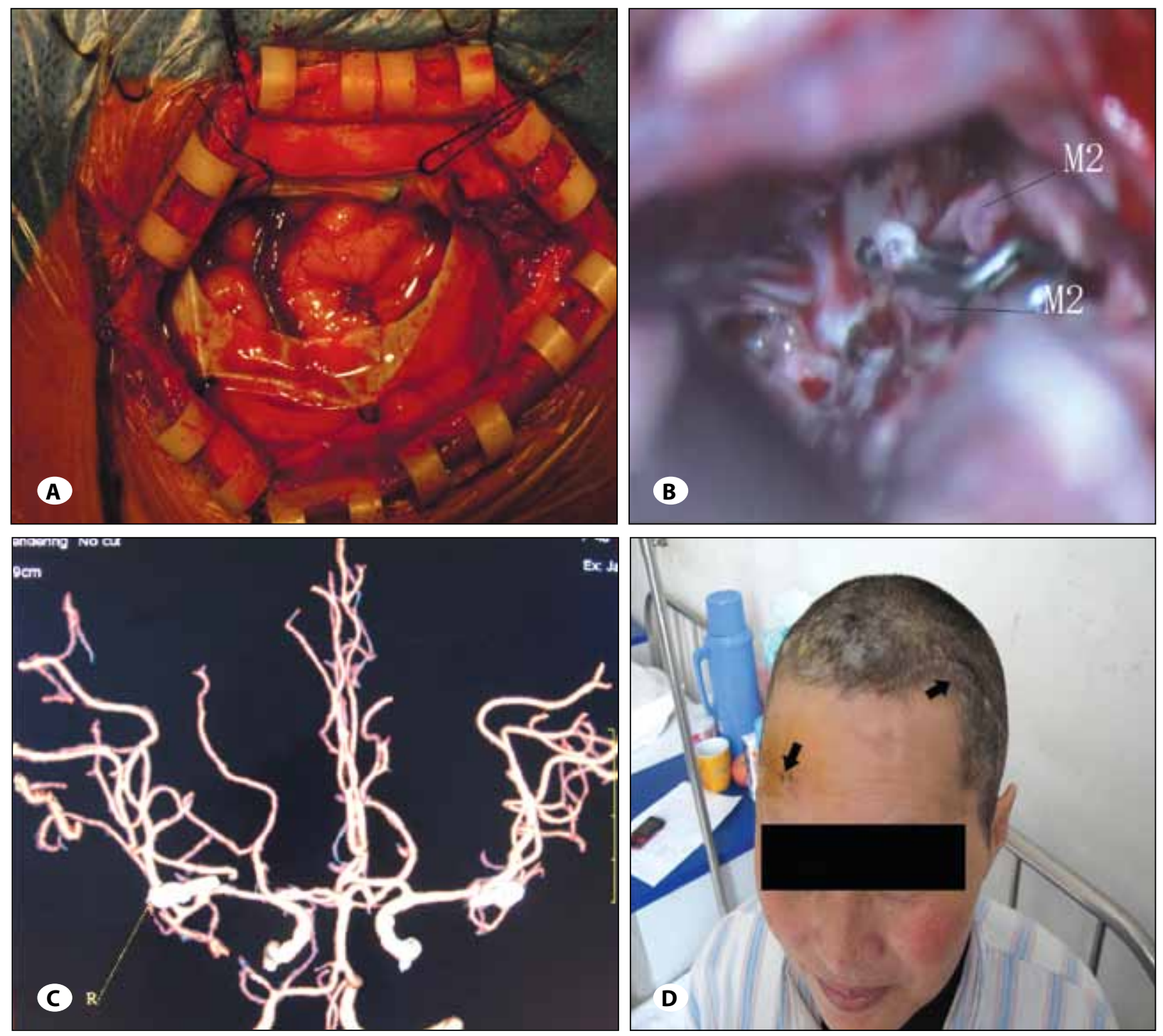

Figure 2: The patient is a 48-year-old woman wih the MCA aneurysms on both sides. Traditional frontotemporal craniotomy was used in the surgical clipping of left MCA aneurysm in other hospital. 3 monthes later, a supraorbital keyhole approach through a front wrinkle skin incision was applied to clip the right MCA aneurysm in our hospital. (A) surgical exposure after a right supraorbital keyhole cranitomy and dural opening. (B) intraoperative photograph: the aneurysms was clipped. (C) AP view of angiography after MCA aneurysms on both sides were clipped (D) photographs showing cosmetic results after different cranitomy. Sugical scar (arrow): left surgical scar 3 months postoperatively and right surgical scar 7 days postoperatively.

Regarding multiple aneurysm, we usually manipulate these multiple aneurysms during one surgical session, based on our experience, it should be comfortable when the contralateral aneurysms clipped, because of relaxed brain and a lot of space for surgical manipulation as a benefit from the contralateral CSF drainage. For some cases of aneurysms accompanied with contralateral aneurysms, a bilateral supraorbital keyhole approach was used to clip all aneurysms during one surgical session, in 4 cases listed as below, they were all clipped successfully.

The strategy of clip reconstruction of the aneurysm and circumferential study of and occlusion of the aneurysm is limited for its limited bony opening. In our cases, however, endoscopic assistance was not used to expand the reach of the approach, the aneurysms were carefully selected, we perform this approach only when we are confronted with nonruptured aneurysms or ruptured aneurysms in good neurological grade (I-III of hunt and Kosnik calcification), and the visualization of neck of aneurysms should be adequate with less retraction.

\section{CONCLUSION}

The supraorbital keyhole approach provides minimally invasive access for the majority of antieror communicating artery aneurysms with an excellent cosmetic result and rapid 
patient recovery relative to traditional lager craniotomies. In addition, the wrinkle incision described by us can offer a similar cosmetic results while decreaing the risk of eyebrow incision. Nevertheless, this approach cannot be a standard approach for all lesions, it can be applied to only very special aneurysms with an intense preop evaluation and in very skilled hands, the decision to approach these aneurysms by supraorbital craniotomies should be based on aneurysms features, size, growth pattern, and the surgeon's experience, we cleanly outline some of the aneurysms with this approach to be difficult.

\section{REFERENCES}

1. Dare AO, Landi MK, Lopes DK Grand W: Eyebrow incision for combined orbital osteotomy and supraorbital minicraniotomy application to aneurysms of the anterior circulation. Technical note. J Neurosurg 95: 714-718, 2001

2. Georgeol, J, Laszlo B: Eyebrows surgery: The supraciliary craniotomy: Technical note. Neurosurgery 59: 157-158, 2006
3. Grand W, Landi MK, Daré AO: Transorbital keyhole approach to anterior communicating artery aneurysms. Neurosurgery 49: 483-484, 2001

4. Mitchell P, Vindlacheruvu RR, Mahmood K, Ashpole RD, Grivas A, Mendelow AD: Supraorbital eyebrow minicraniotomy for anterior circulation aneurysms Surgical Neurology 63:47-51, 2005

5. Reisch R, Perneczky A:Ten-year-experience with the supraorbital approach through an eyebrow skin incision. Neurosurgery 57:242-255, 2005

6. Reisch R, Perneczky A, Filippi R: Surgical technique of the supraorbital key-hole craniotomy. Surg Neurol 59:223-227, 2003

7. Solomon RA: Anterior communicating artery aneurysm Neurosurgery 48: 119-123, 2001

8. Steiger HJ, Schmid-Elsaesser R, Stummer W, Uhl E: Transorbital keyhole approach to anterior communicating artery aneurysms. Neurosurgery 48: 347-351; discussion 351-352, 2001 